Cellular Physiology
and Biochemistry

Cell Physiol Biochem 2013;32(suppl 1):14-31 \begin{tabular}{l|l}
\hline DOI: $10.1159 / 000356621$ & C 2013 S. Karger AG, Basel
\end{tabular}

Published online: December 18, 2013

www.karger.com/cpb

1421-9778/13/0327-0014\$38.00/0

This is an Open Access article licensed under the terms of the Creative Commons AttributionNonCommercial 3.0 Unported license (CC BY-NC) (www.karger.com/OA-license), applicable to the online version of the article only. Distribution permitted for non-commercial purposes only.

Review

\title{
A Molecular Analysis of the $\mathrm{Na}^{+}-$ Independent Cation Chloride Cotransporters
}

\author{
Kenneth B. Gagnon ${ }^{a} \quad$ Mauricio Di Fulviob \\ aDepartment of Anatomy and Cell Biology, University of Saskatchewan, Saskatoon, SK, Canada; \\ bDepartment of Pharmacology and Toxicology, Wright State University, Boonshoft School of Medicine, \\ Dayton, $\mathrm{OH}$, USA
}

\author{
Key Words \\ SLC12A $\cdot$ Variants $\cdot$ Gene $\cdot$ Volume $\cdot$ Regulation
}

\begin{abstract}
The homologous genes encoding the electroneutral solute carrier family 12A (SLC12A) were identified more than 20 years ago, however, over the last few years, it has become clear that each of the genes within this family potentially encode for more than one cationchloride cotransporter (CCC). Even more surprising, despite more than 30 years of functional studies and a wealth of knowledge on the activators, inhibitors, ion affinities, and kinetics of these cotransporters, we still cannot sufficiently explain why some cells express only one CCC isoform, while others express two, three, or more CCC isoforms. In 2009, Drs. AlvarezLeefmans and Di Fulvio published an extensive in silico molecular analysis of the potential splice variants of the $\mathrm{Na}^{+}$-dependent cation-chloride cotransporters. In this review, we will look at the exceptionally large variety of potential splice variants within the $\mathrm{Na}^{+}$-independent cation-chloride cotransporter (SLC12A4-SLC12A7) genes, their initial tissue identification, and their physiological relevance.
\end{abstract}

Copyright (C) 2013 S. Karger AG, Basel

\section{Introduction}

The electroneutral solute carrier family $12 \mathrm{~A}(S L C 12 \mathrm{~A})$ transport family comprises at least seven branches of homologous genes i.e., SLC12A1-7 [reviewed in [1]] (Table 1). Each of these genes encodes unique cation-chloride cotransporter (CCC) isoforms. Two additional 


\section{Cellular Physiology Cell Physiol Biochem 2013;32(suppl 1):14-31

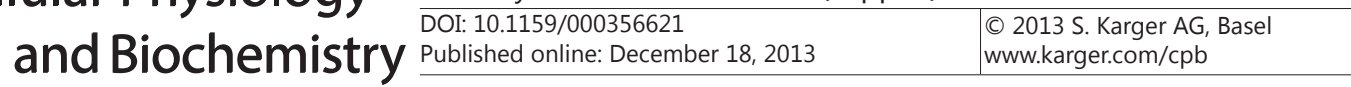 \\ Gagnon/Di Fulvio: Molecular Analysis of K-Cl Cotransporters}

genes, SLC12A8 (cation-chloride cotransporter 9, CCC9) and SLC12A9 (cation-chloride cotransporter-interacting protein 1, CIP1) have also been proposed to be part of the SLC12A family based on a relatively weak $(\sim 20 \%)$ amino acid sequence identity between CCC9/ CIP1 and the other members of the SLC12A family. Indeed, a common evolutionary origin and inclusion of CCC9/CIP1 in the SLC12A family needs to be inferred from functional data or common in silico predicted structures [1]. Interestingly, CCC9 transports polyamines in a furosemide-sensitive, amino acid-dependent and $\mathrm{Na}^{+} / \mathrm{K}^{+} / \mathrm{Cl}^{-}$-independent fashion [2], whereas CIP1 is not associated with $\mathrm{Na}^{+}, \mathrm{K}^{+}$or $\mathrm{Cl}^{-}$cotransport, but does share common predicted structural features with members of the $S L C 12 \mathrm{~A}$ family and is able to interact and potentially inhibit the function of the $\mathrm{Na}-\mathrm{K}-2 \mathrm{Cl}$ cotransporter (NKCC1) [3]. Clearly, additional phylogenetic and functional analyses are needed in order to include or exclude CCC9 or CIP1 from the $S L C 12 A$ family.

The SLC12A1, SLC12A2, and SLC12A3 genes encode the two Na-K-2Cl and one $\mathrm{Na}-\mathrm{Cl}$ cotransporters, respectively. Together, these plasma membrane transport proteins represent the $\mathrm{Na}^{+}$-dependent cation-chloride cotransporter branches of the $S L C 12 \mathrm{~A}$ family. Each of these cotransporters is involved in the electroneutral accumulation of $\mathrm{Cl}^{-}$using the energy stored in the combined $\mathrm{Na}^{+}, \mathrm{K}^{+}$, and $\mathrm{Cl}^{-}$chemical gradients [reviewed in [4]]. An extensive in silico analysis of the potential splice variants of the $\mathrm{Na}^{+}$-dependent cation-chloride cotransporters (SLC12A1-SLC12A3) was published recently [1]. Therefore, in this review, we will focus on potential splice variants within the $\mathrm{Na}^{+}$-independent cation-chloride cotransporters and the functional implications of the multi-isoform expression of these transport proteins in various cell types.

The protein products of the SLC12A4-SLC12A7 genes, commonly known as the $\mathrm{K}-\mathrm{Cl}$ cotransporters, are also involved in cell volume regulation, however, as $\mathrm{Cl}^{-}$extruders, they maintain the intracellular chloride concentration $\left(\left[\mathrm{Cl}^{-}\right]_{\mathrm{i}}\right)$ below the values predicted by thermodynamic equilibrium. Under normal physiological conditions, the driving force for each of these $\mathrm{K}-\mathrm{Cl}$ cotransporters to extrude $\mathrm{Cl}^{-}$from cells comes from the chemical energy derived from the outwardly directed differential $\mathrm{K}^{+}$concentration gradient across the cell membrane $[1,5]$. In fact, only a small shift in the extracellular concentration of $\mathrm{K}^{+}$can result in a reversal from $\mathrm{Cl}^{-}$extrusion to $\mathrm{Cl}^{-}$accumulation [6].

At the pharmacological level, each of the $\mathrm{K}-\mathrm{Cl}$ cotransporters (KCC1-KCC4) is inhibited by relatively high concentrations of the diuretics bumetanide or furosemide [7, 8]. In addition, certain non-specific drugs such as 4, 4'-diisothiocyano-2, 2'-stilbene-disulfonic acid (DIDS) or dihydroindenyl-oxyacetic acid (DIOA) [9-11] have also been reported to inhibit KCC activity $[12,13]$. Although there are no specific drugs able to block KCC1 and KCC4 activity, new highly selective and specific inhibitors of KCC2 and KCC3 have recently been characterized and optimized [14,15].

When analyzed in silico, the predicted amino acid sequences of the KCCs show the potential to adopt similar topologies consisting of 12 transmembrane domains flanked by two large intracellular N-and C-termini [16-20]. For most members of the SLC12A family, the functional properties of these cotransporters have been extensively studied in heterologous expression systems [reviewed in [21]]. However, we still have little knowledge regarding the molecular mechanisms involved in SLC12A gene expression regulation in mammalian cells. In addition, for many of these heterologous expression studies, the multiple splice variants of the KCCs are not even considered. This lack of information needs to be addressed to fully understand the individual contribution of each isoform to the total functional KCC pool. The consensus is that each isoform extrudes $\mathrm{K}^{+}$and $\mathrm{Cl}^{-}$ions as part of the general machinery responsible for cell volume regulation [5]. Interestingly, several reports using genetically modified mice with targeted disruption of specific KCC isoforms have resulted in some surprising phenotypes. A recent review by Drs. Gagnon and Delpire has described in great detail the result of targeted disruption of both individual and multiple KCC isoforms [22]. Collectively, targeted knockout of specific KCC isoforms has demonstrated two central themes: 1) there is some functional reciprocity amongst the isoforms i.e., down-regulation of one isoform can be offset partially or completely by up-regulation of another isoform; and 2) 


\section{Cellular Physiology Cell Physiol Biochem 2013;32(suppl 1):14-31 \begin{tabular}{l|l|l} 
DOI: 10.1159/000356621 & (c) 2013 S. Karger AG, Basel
\end{tabular} and Biochemistry Publisned onine: December 18, 2013 www.karger.com/cpb}

Table 1. Variants of the KCCs. Shown are the $S L$ C12A4, SLC12A5, SLC12A6 and SLC12A7 genes defined by unique gene identification numbers (noted between parentheses), their products named by the most commonly used acronyms (i.e., KCC1, KCC2, KCC3 and KCC4) followed by suffixes indicating splice variants. Also shown are the accession numbers for each artificially created mRNA or protein sequence of reference (RefSeq database). When available, accession numbers posted in GenBank database and the tissue/cell sources from where those sequences were obtained are also indicated. Note: RefSeq accession numbers are defined by a unique prefix format consisting of two characters, an underscore (e.g. $\mathrm{NM}_{-}, \mathrm{NP}_{-}, \mathrm{XM}_{-}$, or $\mathrm{XP}_{-}$)

\begin{tabular}{|c|c|c|c|c|c|}
\hline Human Gene (ID) & $\begin{array}{l}\text { Spliced } \\
\text { Variants }\end{array}$ & $\begin{array}{l}\text { Reference } \\
\text { mRNAs }\end{array}$ & $\begin{array}{l}\text { Reference } \\
\text { Proteins }\end{array}$ & $\begin{array}{l}\text { Supporting } \\
\text { full-length } \\
\text { cDNA clones }\end{array}$ & $\begin{array}{l}\text { Source of } \\
\text { cDNA clones }\end{array}$ \\
\hline SLC12A4 (6560) & $\begin{array}{l}\text { KCC1a } \\
\text { KCC1b } \\
\text { KCC1c } \\
\text { KCC1d } \\
\\
\text { KCC1e } \\
\text { KCC1f } \\
\text { KCC1g } \\
\text { KCC1h } \\
\text { KCC1i }\end{array}$ & $\begin{array}{l}\text { NM_005072 } \\
\text { NM_001145961 } \\
\text { NM_001145962 } \\
\text { NM_001145963 } \\
\text { NM_001145964 }\end{array}$ & $\begin{array}{l}\text { NP_005063 } \\
\text { NP_001139433 } \\
\text { NP_001139434 } \\
\text { NP_001139435 } \\
\text { NP_001139436 }\end{array}$ & $\begin{array}{l}\text { BC021193 } \\
\text { AK293906 } \\
\text { AK293956 } \\
\text { AK302790 } \\
\text { AK316415 } \\
\\
\text { AK299042 } \\
\text { AF047338 } \\
\text { AF054506 } \\
\text { AF054505 }\end{array}$ & $\begin{array}{l}\text { retinoblastoma } \\
\text { cerebellum } \\
\text { cerebellum } \\
\text { testis } \\
\text { testis } \\
\text { teratocarcinoma } \\
\text { erythroleukemia } \\
\text { erythroleukemia } \\
\text { erythroleukemia }\end{array}$ \\
\hline SLC12A5 (57468) & $\begin{array}{l}\text { KCC2a } \\
\text { KCC2b } \\
\\
\text { KCC2b-s1 } \\
\text { KCC2b-s2 } \\
\text { KCC2b-s3 }\end{array}$ & $\begin{array}{l}\text { NM_001134771 } \\
\text { NM_020708 }\end{array}$ & $\begin{array}{l}\text { NP_001128243 } \\
\text { NP_065759 }\end{array}$ & $\begin{array}{l}\text { BC132668 } \\
\text { BC132670 } \\
\text { AK289758 } \\
\text { AB033002 } \\
\text { AF208159 } \\
\text { AK294059 } \\
\text { AK295096 } \\
\text { AK098371 }\end{array}$ & $\begin{array}{l}\text { pooled tissues } \\
\text { pooled tissues } \\
\text { brain } \\
\text { brain } \\
\text { brain } \\
\text { cerebellum } \\
\text { brain } \\
\text { brain }\end{array}$ \\
\hline SLC12A6 (9990) & $\begin{array}{l}\text { KCC3a } \\
\text { KCC3b } \\
\text { KCC3C (a-s1) } \\
\text { KCC3d (a-s2) } \\
\text { KCC3e (a-s3) } \\
\text { KCC3f (a-x2M) }\end{array}$ & $\begin{array}{l}\text { NM_133647 } \\
\text { NM_005135 } \\
\text { NM_001042494 } \\
\text { NM_001042495 } \\
\text { NM_001042496 } \\
\text { NM_001042497 }\end{array}$ & $\begin{array}{l}\text { NP_598408 } \\
\text { NP_005126 } \\
\text { NP_001035959 } \\
\text { NP_001035960 } \\
\text { NP_001035961 } \\
\text { NP_001035962 }\end{array}$ & $\begin{array}{l}\text { AF105366 } \\
\text { AF116242 } \\
\text { AF108831 } \\
\text { BC126241 } \\
\text { BC126243 } \\
\text { AK315283 } \\
\text { AF531259 } \\
\text { AF477977 } \\
\text { AF531260 } \\
\text { BC070107 } \\
\text { DQ138323 } \\
\text { AF531258 }\end{array}$ & $\begin{array}{l}\text { placenta } \\
\text { endothelial cells } \\
\text { brain, cerebellum } \\
\text { brain, cerebellum } \\
\text { uterus } \\
\text { testis } \\
\text { testis }\end{array}$ \\
\hline SLC12A7 (10723) & $\begin{array}{l}\text { KCC4a } \\
\text { Unnamed } \\
\text { Unnamed }\end{array}$ & NM_006598 & NP_006589 & $\begin{array}{l}\text { AF105365 } \\
\text { BC098390 } \\
\text { BC007760 } \\
\text { BC018982 } \\
\text { AK302856 }\end{array}$ & $\begin{array}{l}\text { kidney } \\
\text { testis } \\
\text { neuroblastoma } \\
\text { neuroblastoma } \\
\text { testis }\end{array}$ \\
\hline
\end{tabular}

and 6-9 digits. GenBank accession numbers are most commonly defined by the use of an alphanumerical code represented by two capital letters followed by 6 digits (e.g., BC021193 or AF116242). Contrary to RefSeq, GenBank database annotates experimentally obtained sequences.

the possibility exists that these transporters may participate in cellular functions not related to their ion transport capabilities, as recently described for some KCC isoforms [23-26].

\section{SLC12A4 (KCC1)}

Molecular aspects

In silico analysis, coupled to complementary deoxyribonucleic acid/expressed sequence tags (CDNA/EST) alignment, reveals the presence of 13 putative promoters, 9 nonoverlapping alternative last exons, and 6 validated alternative poly-adenylation sites in the human KCC1 (hKCC1) gene i.e., SLC12A4. Clearly, the SLC12A4 gene has the potential to direct transcription of several different mRNAs (Fig. 1A). Interestingly, some of the hKCC1 cDNAs posted in GenBank are shorter, incomplete, or predicted to encode proteins either not related to KCC1 or not likely to have ion transport capabilities. Although the functional impact of these smaller transcripts is unknown, current evidence suggests that the human SLC12A4 gene (referenced mRNAs in RefSeq database, see Table 1) has the capacity to produce at least five $\mathrm{K}-\mathrm{Cl}$ cotransport proteins by alternative splicing of the first four exons (Fig. 1A). Accordingly, based on the nucleotide differences of several KCC1 cDNAs, RefSeq has annotated five hKCC1 nucleotide sequences: NM_005072 (hKCC1a), NM_001145961 (hKCC1b), NM_001145962 (hKCC1c), NM_001145963 (hKCC1d) and NM_001145964 (hKCC1e). It is important to note 


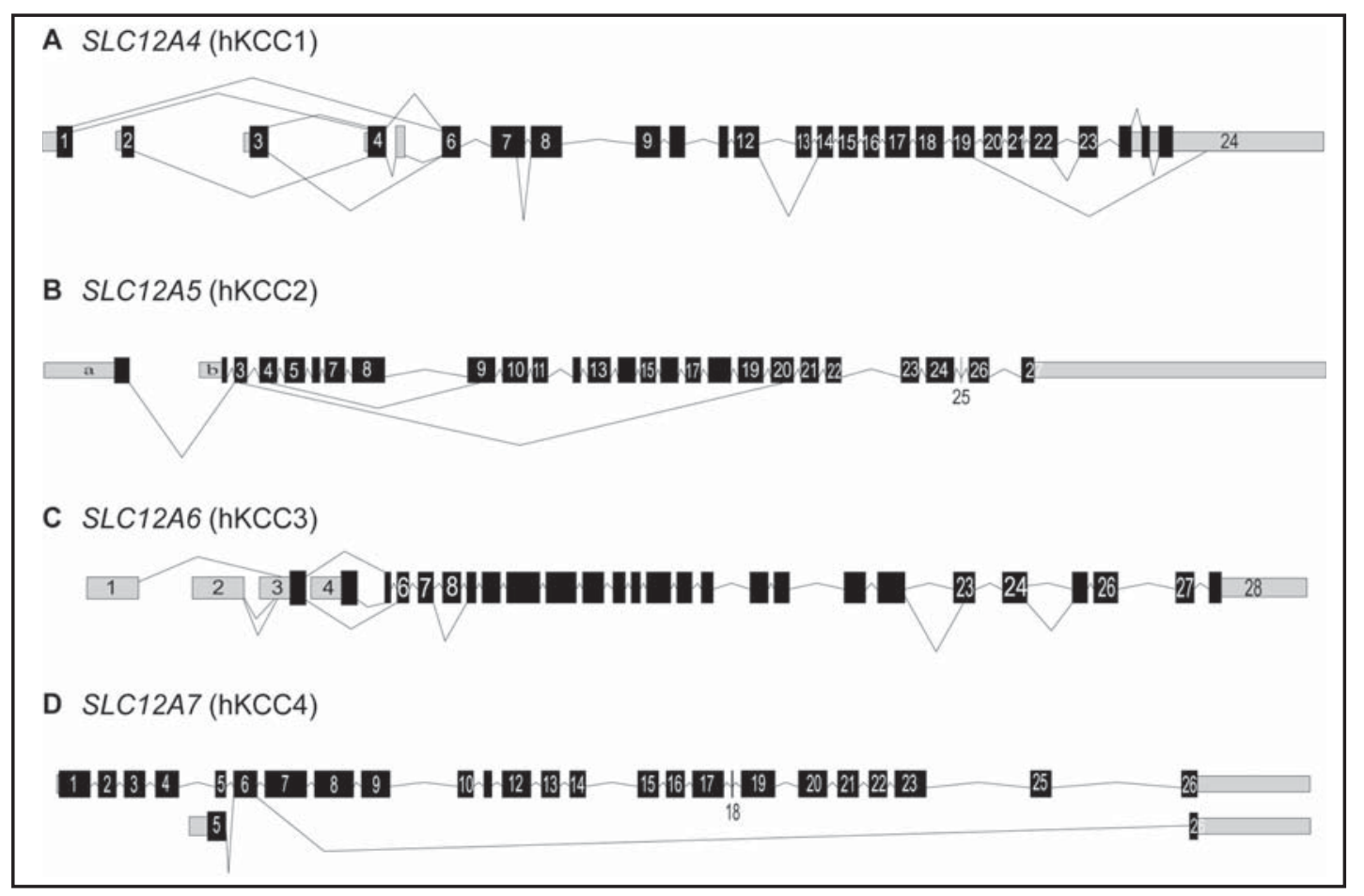

Fig. 1. Exon organization of the SLC12A4-7 genes and their alternative splicing. Shown are non-scale diagrams of the exons forming part of (A) SLC12A4 (hKCC1), (B) SLC12A5 (hKCC2), (C) SLC12A6 (hKCC3) and (D) SLC12A7 (hKCC4) genes. These exons are depicted as boxes interconnected by lines representing alternative joining observed in full-length cDNAs posted in GenBank, which are the supporting clones of RefSeq mRNAs (see Table 1). Coding (black boxes) and non-coding (grey boxes) exons are numbered progressively as they appear in the genes from 5 ' to 3 '. Some genes may have exons with both coding and non-coding capabilities once in the transcripts and thus, these exons are indicated as combined grey and black boxes.

that more KCC1 RefSeqs might be on their way to fully reflect the hKCC1 transcriptome. Thus far, RefSeqs reflecting differences in the 3'-ends of hKCC1 cDNAs have not been generated yet, in spite of the fact that full-length hKCC1 cDNAs with different splicing involving the last exon do exist i.e., AF054505 and AF054506 [27] (see Table 1). It is interesting to note that several potential initiation codons are present in the mRNAs of reference, suggesting the possibility that more than one open reading frame (ORF) may be operative. In addition, in silico alignment of hKCC1 sequences posted in GenBank makes it clear that while several of these hKCC1 mRNAs have identical or similar ORFs, differences exist in their 5'-untranslated regions (5'-UTRs) suggesting potential molecular signaling mechanisms that might affect the molecular expression, translation, and possible function of the encoded cotransport proteins.

For the purpose of this review, in this section we will focus on the hKCC1 sequences resulting from alternative splicing of exons 1-4 based on the prediction that these transcripts would produce hKCC1 proteins differing mostly in their N-termini (Fig. 2), the region that contains the most variability among KCCs and potential regulatory sites [5]. It is also important to note that deletion of the N-terminal region of KCC1 resulted in a functionally dominant negative effect when co-expressed with the other $\mathrm{K}-\mathrm{Cl}$ cotransporters in Xenopus laevis oocytes $[28,29]$. In exon 1 , there are two non-overlapping first codons $\left(\mathrm{A}^{41} \mathrm{UG}\right.$ and $\mathrm{A}^{142} \mathrm{UG}$ ) where the numbering reflects the nucleotide position relative to the first one of the exon. The first AUG codon encodes for the initiating methionine $\left(\mathrm{M}^{1}\right)$ of hKCC1c, whereas the second AUG codon encodes for the $\mathrm{M}^{1}$ in hKCC1a and hKCC1b. Exon 2 contains the $\mathrm{M}^{1}$ of the hKCC1e protein. Exon 3 contains the $\mathrm{M}^{1}$ of the hKCC1d protein. Interestingly, exon 4 is absent 


\section{Cellular Physiology Cell Physiol Biochem 2013;32(suppl 1):14-31 \begin{tabular}{l|l}
\hline DOI: 10.1159/000356621 & 2013 S. Karger AG, Basel
\end{tabular} and Biochemistry Publisned online: December 18, 2013 www.karger.com/cpb}

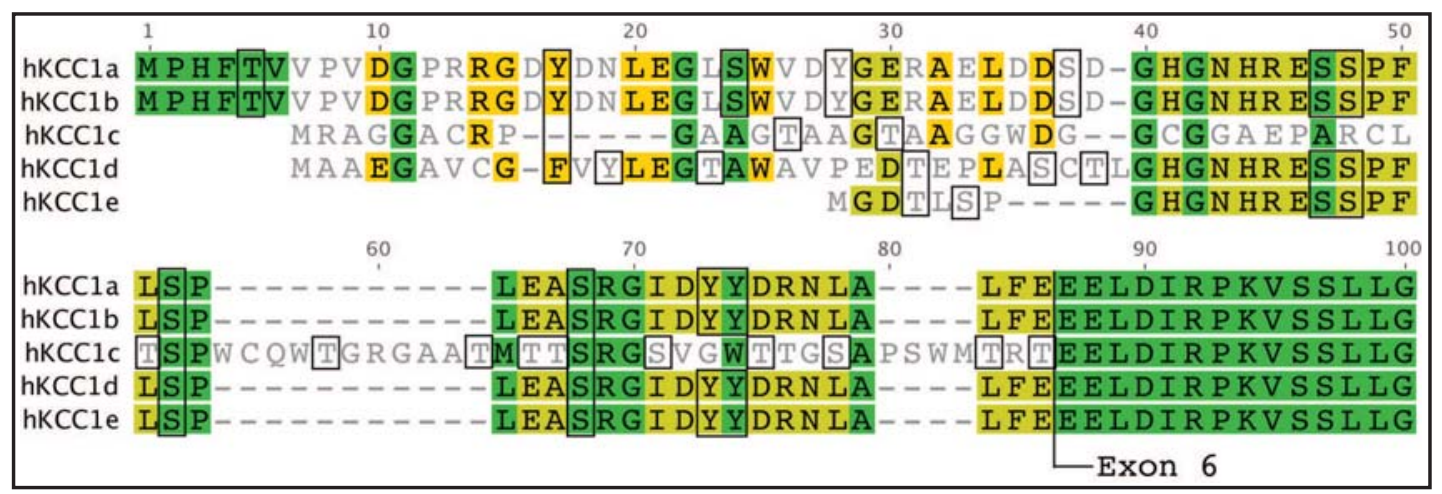

Fig. 2. Alignment of the N-terminal regions of predicted KCC1 spliced variants. Protein sequence alignment performed using the MAFFT v7 algorithm of Katoh et al. [83] of the putative N-terminal regions hKCC1a, b, $\mathrm{c}, \mathrm{d}$ and e. The percentages of similarity among residues, as calculated by the Blosum 90 matrix, are shown in four different colors. Green residues have 100\% identity, light-green residues have $80-99 \%$, yellow residues have $60-79 \%$, and grey residues indicate less than $60 \%$ identity. Potential sites of kinase-mediated phosphorylation as computationally predicted by KinasePhos (kinasephos.mbc.nctu.edu.tw) are indicated within open boxes.

only in hKCC1c, whereas exons 2 and 3 are present in hKCC1e and KCC1d, respectively. The sequence GTG GAG GTG GTG GAG ATG corresponding to the last 18 nucleotides in exon 23 is spliced out in $\mathrm{hKCC} 1 \mathrm{~b}$. This splicing event predicts the expression of a cotransporter protein shortened by 6 amino acids (VEVVEN) in the putative C-terminal cytoplasmic region. Although SLC12A4 is typically considered a house-keeping gene expressed in most if not all tissues (see Fig. 3), the expression pattern or functional significance of the different hKCC1 transcripts in different human tissues is currently unknown.

\section{Functional and physiological aspects}

Clearly, the high variability in hKCC1 transcripts not only reflects the potential of the SLC12A4 gene to produce cotransporter proteins with different functional or regulatory properties, but also points towards the potential significance of different hKCC1s in the regulation of cell volume or [Cl- $]_{\text {: }}$. This is particularly appealing when we consider KCC1 as a "housekeeping" gene expressed in all cells. Interestingly, hKCC1 appears to be expressed at low levels relative to other KCCs (Fig. 3, filled circles) and absence of functional KCC1 in rodents ( $\mathrm{KCC}^{\mathrm{KO}}$ mice) does not result in overt phenotypic abnormalities [30]. The absence of obvious clinical manifestations in these mice suggest that KCC1 may be a functionally redundant gene whose activity may be replaced by other KCC members or any other gene with similar overall functions. In addition, different KCC1 variants with different regulatory properties may exist in rodents but not in humans or vice versa. In fact, two KCC1 variants have been described in the mouse, which in turn are not the result of splicing events homologous to the ones found in the human counterpart. Indeed, mKCC1a (NM_001253804) and mKCC1b (NM_009195) differ among themselves by the inclusion of the last six nucleotides (GGUGAG) of the first exon of the mouse Slc12a4 gene. This translates into a difference of two amino acids (glycine, glutamic acid) in the mature mKCC1 protein. Whether or not these two extra amino acids confers different functional properties to the rodent KCC1 is currently unknown, but suggests that caution should be paid when interpreting results using different models or species.

\section{SLC12A5 (KCC2)}

\section{Molecular aspects}

The human KCC2 gene (hKCC2, SLC12A5, Gene ID 57468) encodes full-length transcripts, which are predicted to generate several KCC2s or shorter SLC12A5-driven transcripts 


\section{Cellular Physiology Cell Physiol Biochem 2013;32(suppl 1):14-31 \begin{tabular}{ll|l} 
and Biochem 10.1159/000356621 & $\begin{array}{l}\text { O 2013 S. Karger AG, Basel } \\
\text { www.karger.com/cpb }\end{array}$ \\
\cline { 2 - 3 }
\end{tabular}}

Fig. 3. Expression pattern of hKCC transcripts in human tissues and cells. Transcript expression levels were obtained from the gene atlas of the human transcriptome published by $\mathrm{Su}$ et al. [84] and posted in the publicly available database GEO Profiles (record GDS596). The expression profile of hKCC1 (filled circles), hKCC2 (open circles), hKCC3 (open squares) and hKCC4 (filled squares) mRNAs was quantified by using the following probe sets: 209400_at (hKCC1), 210040_ at (hKCC2), 220740_s_at (hKCC3) and 218066_at (hKCC4). Results are shown as absolute levels of mRNA expression in arbitrary units. Raw data can be accessed at www.ncbi.nlm.nih. gov/sites/GDSbrowser?acc=GDS596.

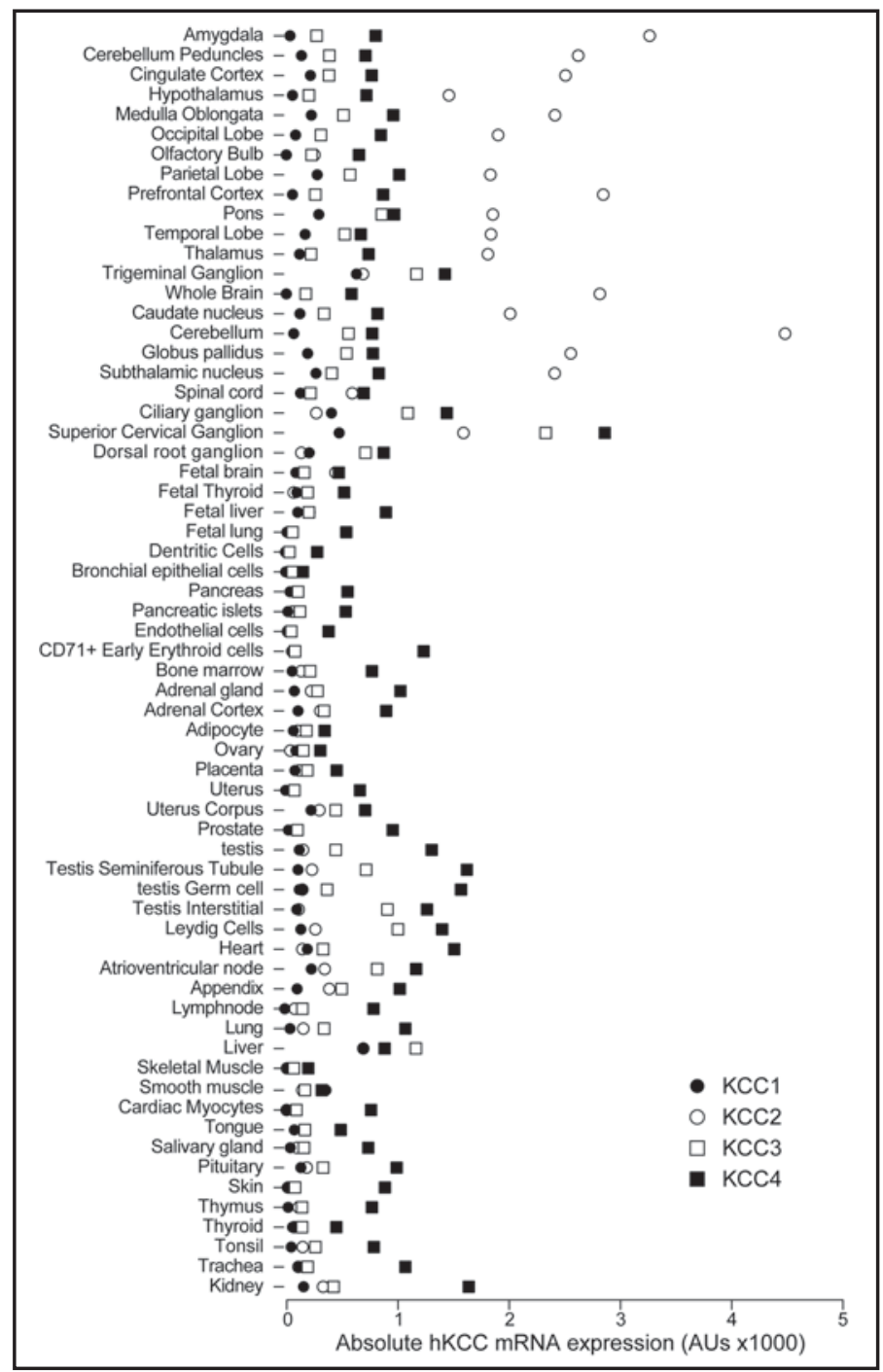

(AK098371, AK294059, AK295096), which are predicted to encode proteins with potential functional properties not related to ion transport. The SLC12A5 gene transcribes at least two functional splice variants of hKCC2, both annotated as two transcripts of reference: NM_001134771 (hKCC2a) and NM_020708 (hKCC2b). The KCC2a variants are predicted to exist based on the inclusion of one of two mutually exclusive first exons located $7.2 \mathrm{~kb}$ apart from each other in the most distal 5' region of the vertebrate Slc12a5 genes, two human ESTs showing direct splicing of exon 1a and exon 2 (DA102113 and DA328785), and a fulllength cDNA from embryonic day E18 rat hippocampus [EF641113 [31]]. Inclusion of exon 1 (exon 1a) or exon 2 (exon 1b) in the mature hKCC2 transcript depends on the election of two different promoters located 5' of each first exon plus a combined event of splicing in the case of the former but not in the latter (Fig. 4A). Inclusion of exon 1 in hKCC2 mRNAs creates hKCC2a, a transcript predicted to encode cotransporter proteins with unique $40 \mathrm{~N}$-terminal amino acids [31]. If instead of the first exon, the second exon of the SLC12A5 gene is included in hKCC2 mRNAs, the hKCC2b variant is formed, the original variant cloned from neurons [17]. In addition to hKCC2a and hKCC2b, in silico analysis of full-length hKCC2b cDNAs posted in GenBank (i.e., AK294059, AK295096, and AK098371) suggest that hKCC2b pre-mRNAs may be subjected to additional splicing events. In Figure 4A, there are four full-length hKCC2 cDNAs: AF208159 [32], BC132668, BC132670 [33] and AK289758. In silico analysis also revealed three hKCC2b transcripts: hKCC2b-s1 (AK294059) created by exclusion of exons 4-9, hKCC2b-s2 (AK295096) created by exclusion of exons 3-20, and hKCC2b-s3 (AK098371) 


\section{Cellular Physiology Cell Physiol Biochem 2013;32(suppl 1):14-31 \begin{tabular}{l|l} 
DOI: 10.1159/000356621 & O 2013 S. Karger AG, Basel
\end{tabular} and Biochemistry Published online: December 18, 2013 www.karger.com/cpb}

Fig. 4. Transcript variants of the SLC12A5 gene. (A) Depicted are representative full-length cDNAs of hKCC2a transcripts (accession numbers DA102113 and DA328785) and hKCC2b transcripts (accession numbers AK289758, BC132668, BC132670 and AF208159) posted in the GenBank database. There are also two additional shorter transcript variants produced by the SLC12A5 gene (accession numbers AK294059 and AK295096). (B) Alignment of the predicted protein sequences encoded by the cDNAs AK294059 and BC132670 (hKCC2b) using the MAFFT v7 algorithm [83]. Green residues have $100 \%$ identity, light-green residues have $80-99 \%$, yellow residues have $60-79 \%$, and grey residues indicate less than $60 \%$ identity. (C) Protein sequence alignment of the most distal N-terminal

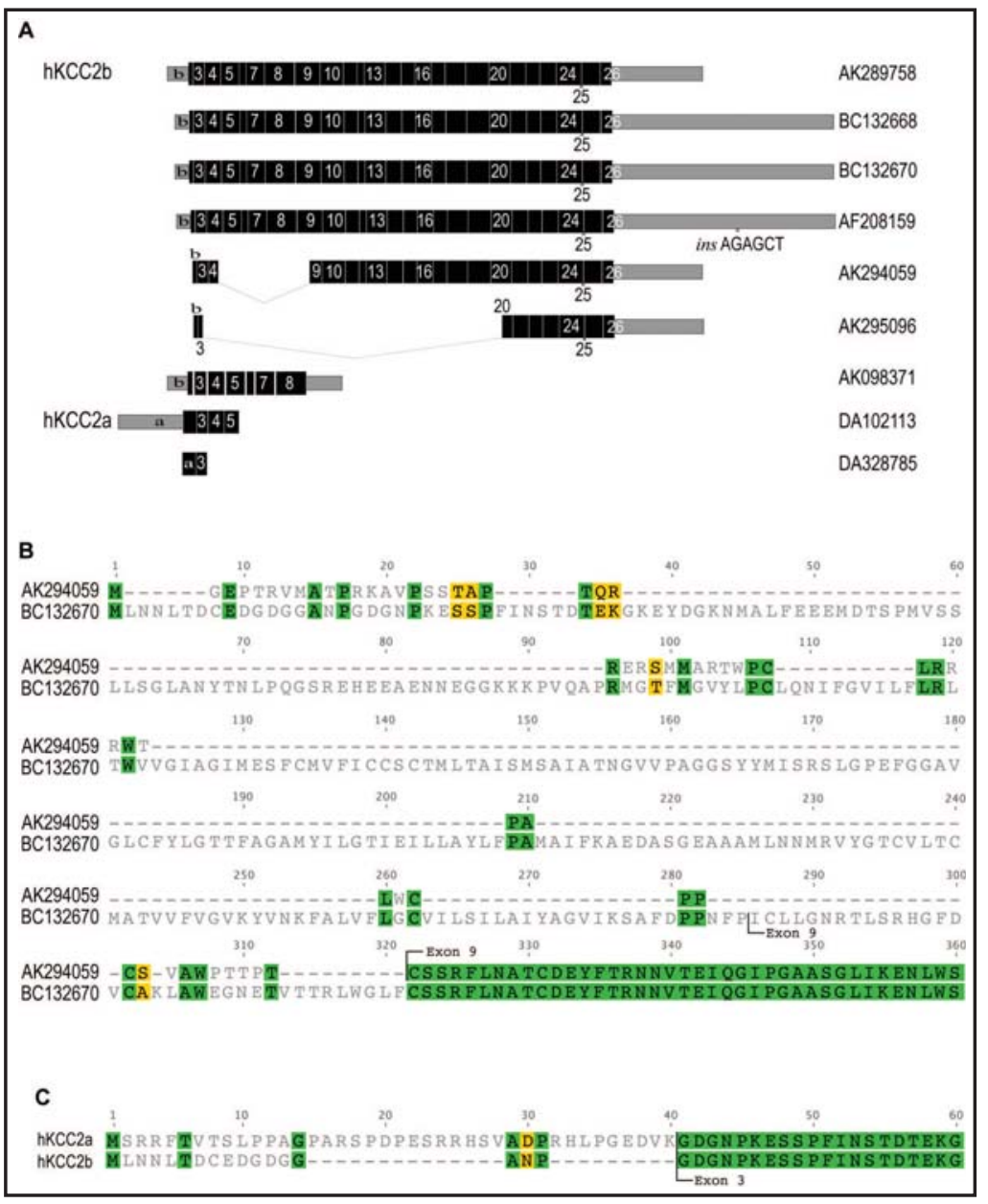
residues of hKCC2a and hKCC2b as predicted by the full-length cDNA AK289758 and the EST DA102113. The full-length cDNAs encoding hKCC2a have either not yet been cloned or posted in the GenBank database.

created by the inclusion of an alternative stop codon located in exon 8. Further potential variability may exist in $\mathrm{hKCC} 2 \mathrm{~b}$ transcripts. Indeed, the potential usage of an alternative AUG codon located $18 \mathrm{bp}$ from the end of exon b (exon 2), absence of the last $65 \mathrm{bp}$ of exon 4, exon 5-8, and the first 112 bp of exon 9 in AK294059 results in a potential protein of 855 amino acids $(\sim 96 \mathrm{kDa})$ with a topology consisting of nine transmembrane domains, an intracellular $\mathrm{N}$-termini with 59 unique residues, and an extracellular C-termini. Apart from the tissues where these cDNAs were cloned, and few examples from non-neuronal cells where KCC2 was detected [25, 34-37], the expression pattern of these transcripts is unknown. Although KCC2 activity has been thoroughly characterized in a variety of heterologous functional experiments, which variant(s) of KCC2b has been expressed and studied has not always been reported.

Finally, although full-length hKCC2a cDNA clones are not yet available, it is important to keep in mind that, similar to KCC1 (see previous section), rodent variants may not be found in humans and vice versa. For example, hNKCC1c is not found in rodents whereas mouse NKCC2A-s1 or -s2 are absent in humans [1]. Similarly, KCC1, KCC3, and KCC4 variants found in humans are not found in mouse and vice versa. Although these transcripts may not encode for proteins with cotransport function, their presence in different tissues may have a regulatory impact on other hKCC2 mRNAs. 


\section{Cellular Physiology Cell Physiol Biochem 2013;32(suppl 1):14-31

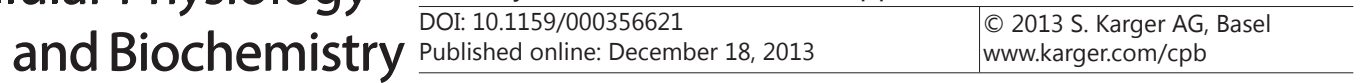 \\ Gagnon/Di Fulvio: Molecular Analysis of K-Cl Cotransporters}

\section{Functional and physiological aspects}

Contrary to the ubiquitous KCC1, the product of the SLC12A5 gene (i.e., KCC2) has long been considered a neuron-specific cotransporter with the notable exception of nociceptive neurons of the dorsal root ganglion where KCC2 expression is very low, if not absent [38]. Neuronal KCC2 is considered the prototypical $\mathrm{Cl}^{-}$extruder, which makes possible the hyperpolarizing or inhibitory effect of gamma-aminobutyric acid (GABA) in mature neurons [39-41]. In spite of the fact that KCC2 is abundantly expressed in central neurons [17], low expression levels of KCC2 have also been documented in several extra-neuronal tissues: rat vascular smooth muscle cells [37], mouse testis [31], human osteoblasts [42], human endometrial cells [25], human lens epithelial cells [34], chicken cardiomyocytes [35] and human pancreatic islets [36]. In fact, KCC2 transcripts may be widely present, although at very low levels when compared to mature neurons of the central nervous system (CNS) (Fig. 3 ). The functional impact of KCC2 expression in extra-neuronal cells is currently unknown.

When functionally compared to the main splice variants of the three additional KCCs i.e., $\mathrm{KCC} 1, \mathrm{KCC} 3$ and $\mathrm{KCC} 4$, rodent $\mathrm{KCC} 2 \mathrm{a}$ and $\mathrm{KCC} 2 \mathrm{~b}$ are constitutively-active cotransporters under normal isotonic conditions, and this activity can be further stimulated under hypotonic conditions $[6,31,41,43,44]$. Therefore, cells expressing KCC2 are expected to express functional extrusion of $\mathrm{Cl}^{-}$and regulatory volume decrease upon cell swelling. However, the relationship between $\mathrm{KCC} 2$-mediated $\left[\mathrm{Cl}^{-}\right]_{\mathrm{i}}$ regulation and $\mathrm{KCC} 2$ 's potential ability to regulate cell volume is still unclear, mostly because the current knowledge regarding KCC2 function comes for experiments only examining the role of $\mathrm{KCC} 2 \mathrm{~b}$ in extruding $\mathrm{Cl}^{-}$from neurons [40, 41]. In addition, targeted deletion [45] or disruption [46] of exon 5 in the mouse Slc12a5 gene eliminates KCC2 expression in mice, resulting in death at birth due to severe motor deficits. Interestingly, targeted elimination of exon $1 \mathrm{~b}$ in the mouse Slc12a5 gene does not completely eliminate mKCC2a expression [31], producing mice that can survive at least for $\sim 12$ days after birth [47]. Although these data suggest that both mKCC2 variants are of vital importance for mice development, they also suggest that the naturally low levels of $\mathrm{mKCC} 2 \mathrm{a}$ are not enough to compensate for the mKCC2b deficiency, and that the latter may be subjected to differential expression regulation. This is in line with the notion that contrary to KCC2a, KCC2b is developmentally regulated [31], raising the possibility that KCC2a may not be as relevant as $\mathrm{KCC} 2 \mathrm{~b}$ in $\left[\mathrm{Cl}^{-}\right]_{\mathrm{i}}$ regulation. However, this latter concept must be taken with caution. Indeed, KCC2a and KCC2b may form hetero-dimers [48, 49], and KCC2b may regulate cell proliferation, neuronal differentiation, migration, and glutamatergic/GABAergic synaptogenesis independently of its transport activity [23-26].

In summary, there is abundant evidence suggesting that KCC2b is a constitutively active cotransporter involved in $\mathrm{Cl}$ - extrusion in neurons and that this activity is what makes possible the hyperpolarizing and inhibitory actions of GABA observed in mature central neurons [39-41]. This concept is especially intriguing when considered within the context of non-neuronal cells co-expressing $\mathrm{KCC} 2$ and the $\mathrm{Cl}^{-}$-channel-coupled GABA receptor, such as cells of the pancreatic islet [36] or the vascular smooth muscle [37]. However, the functional impact of KCC2 in these cells remains to be determined.

\section{SLC12A6 (KCC3)}

\section{Molecular aspects}

At least three SLC12A6gene transcripts ( $7.5 \mathrm{~kb}, 4.3 \mathrm{~kb}$ and $9.0 \mathrm{~kb})$ have been differentially detected in human brain, placenta, skeletal muscle, heart, liver, lung, kidney and pancreas, as well as in several cell lines of human origin [20]. In fact, expression profiling of human tissues demonstrates that KCC3 transcripts are present at different levels in a wide array of human tissues (Fig. 3). In silico analysis of hKCC3 transcripts cloned from different sources and posted in publicly available sequence databases shows that they are the result of alternative election of promoters in the $S L C 12 A 6$ gene, usage of first coding exons and alternative splicing of entire or partial exons (Fig. 1C). These hKCC3 transcripts are identified in the RefSeq 


\section{Cellular Physiology Cell Physiol Biochem 2013;32(suppl 1):14-31

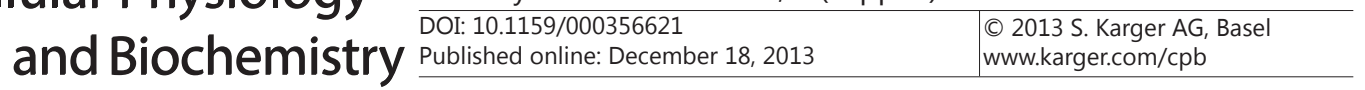 \\ Gagnon/Di Fulvio: Molecular Analysis of K-Cl Cotransporters}

database as: NM_133647 (hKCC3a), NM_005135 (hKCC3b), NM_001042494 (hKCC3c), NM_001042495 (hKCC3d), NM_001042496 (hKCC3e) and NM_001042497 (hKCC3f). Each of these transcripts of reference is in turn defined by at least one unique full-length hKCC3 cDNA (see Fig. 1C and Table 1). Two hKCC3 cDNAs define the hKCC3a transporter [AF105366 $[19,50]$ and AF116242 [20]], as both of them are predicted to encode an identical protein of 1150 amino acids ( 128 kDa). Interestingly, two other transcripts i.e., BC033894 [33] and AK292550, which also encode hKCC3a proteins, differ in their 5'- and 3'-UTRs relative to AF105366 and AF116242. This peculiarity of different transcripts encoding the same protein may reflect potential translational regulatory properties.

The second splice variant of the SLC12A6 gene, hKCC $3 \mathrm{~b}$, is defined by four human full-length cDNA clones obtained from human endothelial cells, cerebellum, and uterus: AF108831 [18], BC126241, BC126243 [33] and AK315283. Each of these cDNAs encode for a protein of 1099 amino acids $(\sim 122 \mathrm{kDa})$. The third variant, hKCC3c, is encoded by two identical cDNAs cloned from human brain and testis: AF531259 [originally named KCC3a-s1, [50]] and AF477977, respectively. Both hKCC3c cDNAs produce a conceptual protein of 1091 amino acids $(\sim 121 \mathrm{kDa})$. The fourth hKCC3 variant, named here hKCC3d, is defined by two cDNAs obtained from human brain and testis: AF531260 [originally named KCC3a-s2 [50]] and BC070107 [33], respectively. These cDNAs are predicted to encode a transporter protein of 1091 amino acids ( 121 kDa). The fifth and sixth variants of hKCC3 (i.e., hKCC3e and hKCC3f) are defined by a single hKCC3 cDNA each: DQ138323 and AF531258 [originally named KCC3a-s3 and KCC3a-x2M, respectively [50]]. These cDNAs representing hKCC3e and hKCC3f are predicted to encode proteins of 1141 and 1135 amino acids ( 127 kDa), respectively.

In silico analysis of these six hKCC3 cDNAs reveals key differences at their 5 '-ends in a region defined by exons 1, 2, 3 and 4 (Fig. 1C). Indeed, inclusion or exclusion of exon 1 and exon 2 coupled to the alternative usage of three different splicing sites in exon 3 that contains three putative initiation codons (AUG) defines the molecular structure of the 5 'UTR and the N-terminal region of hKCC3a, hKCC 3c, hKCC3d, hKCC3e and hKCC3f. In addition, in silico analysis of the aligned hKCC3 cDNAs defining these variants demonstrates that the transcripts lack exon 4, which might be under the command of a second promoter located in intron 3. Therefore, hKCC3a, hKCC3c, hKCC3d, hKCC3e and hKCC3f are the result of transcription from the first promoter of the SLC12A6 gene, alternative splicing of exon 1, 2 and 3 and exclusion of exon 4. Election of the second potential promoter creates hKCC3b. In addition to these complex splicing events, the only other difference between hKCC3a and hKCC $3 \mathrm{f}$ is the exclusion of exon 5 in hKCC3f. It is important to mention that the repertoire of $S L C 12 A 6$ transcripts may not be limited to the variants described above. Indeed, the human SLC12A6 gene has the potential to direct expression of identical hKCC3 proteins by using different transcripts. These mRNAs are the result of alternative election of short 5'-UTR exons, internal splicing, or poly-adenylation sites (Fig. 5). Overall, the existence of these multiple SLC12A6 transcripts predicts a myriad of different hKCC3 proteins (see Fig. 6).

\section{Functional and physiological aspects}

Most of our knowledge about human KCC3a has been learned from studies in mammalian cells and heterologous over-expression in amphibian oocytes [reviewed in [5]]. However, many different KCC3 transcripts may define the pool of functional hKCC3 proteins. In fact, alternative splicing of one mRNA may result in multiple KCC3 proteins responsible for the observed functional activity (Fig. 6). Regardless of the potential multiplicity of SLC12A6 products, overall hKCC3 plays a key role in potassium and chloride homeostasis, cell volume regulation, and electrical responses to GABA and glycine [40]. In fact, hKCC2 and hKCC3, together with NKCCs, are considered part of the regulatory machinery involved in neuronal $\left[\mathrm{Cl}^{-}\right]_{\mathrm{i}}$ regulation [40]. Indeed, absence of KCC3 results in an increased $\left[\mathrm{Cl}^{-}\right]_{\mathrm{i}}$ in neurons [51] and vascular smooth muscle cells [52]. However, unlike hKCC2, hKCC3 has a clear impact in cell volume regulation when over-expressed in cell lines or oocytes, in spite of the fact that only hKCC2 is constitutively-active under isotonic physiological conditions [20, 31, 35]. 


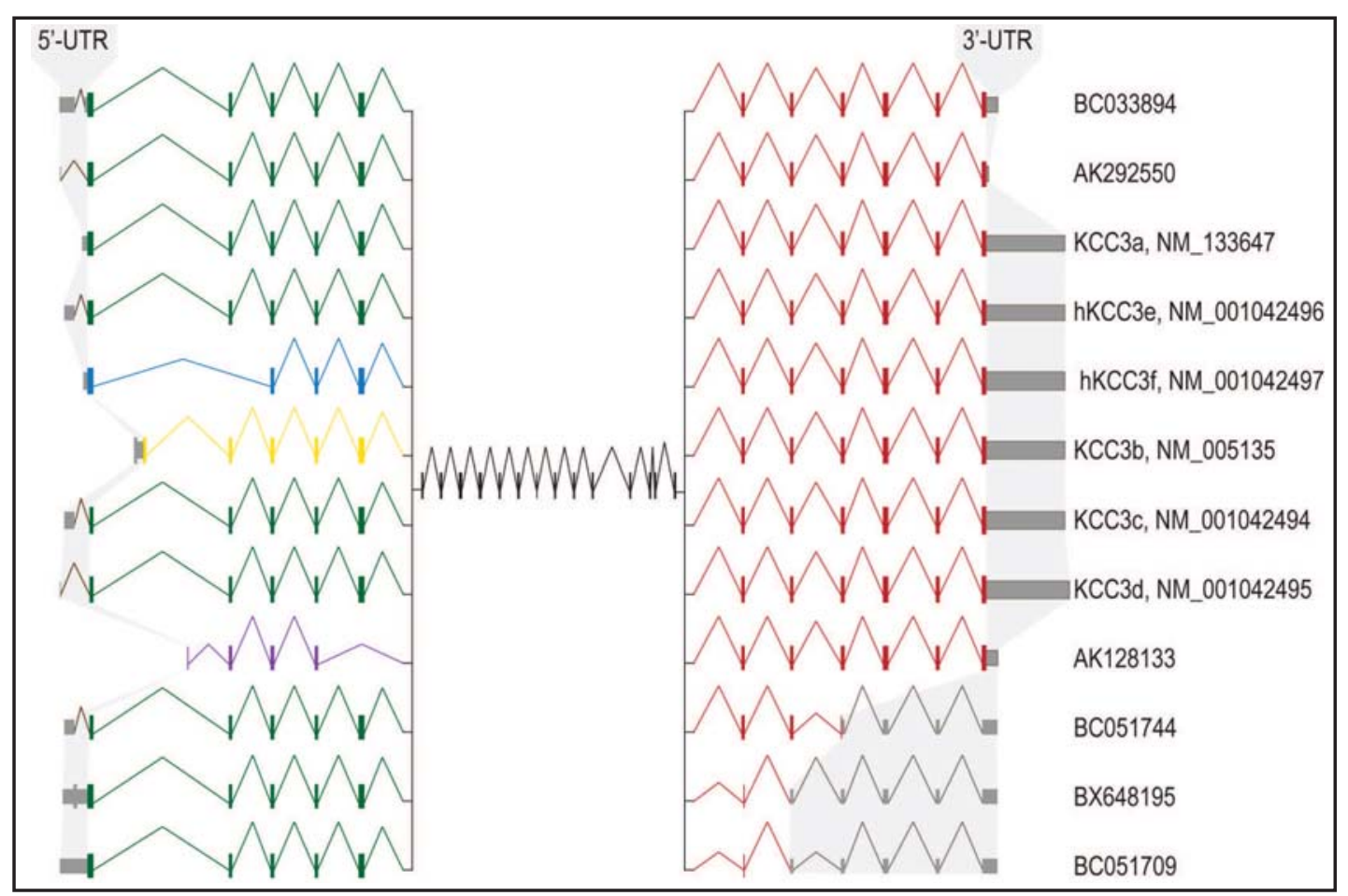

Fig. 5. Transcript variants of the SLC12A6 gene. Represented are multiple human full-length cDNAs products of the transcriptional activity of the human SLC12A6 gene. Exons are indicated as boxes and their potential splicing as lines. Grey boxes represent 5'- or 3'-UTRs and colored boxes indicate identical sequences. Shown are RefSeqs encoding for hKCC3a, b, c, d, e and f (NM_133647, NM_005135, NM_001042494, NM_001042495, NM_001042496 and NM_001042497, respectively). Also shown are potential variants of hKCC3a (BC033894 and AK292550) involving alternative splicing of initial non-coding exons and shorter 3'-UTRs, and four variants characterized by election of internal splicing sites in their 3'-ends and potentially responsible for variability in the C-termini of hKCC3s (AK128133, BC051744, BX648195, and BC051709). These latter variants currently do not have assigned RefSeq accession numbers; therefore, we did not assign single letters to these potential KCC3 variants.

Therefore, in the case of any cell type where both KCC 2 and KCC 3 are co-expressed, it is likely that these cotransporters my play a coordinated but distinctive role in cell volume regulation and $\left[\mathrm{Cl}^{-}\right]_{\mathrm{i}}$ homeostasis under physiological conditions. In fact, recent evidence suggests that KCC3 and KCC2 form oligomers, an association with dominant-negative characteristics, raising the possibility that these KCCs may have mutual co-regulatory properties [53].

Most hKCC3 variants exhibit hypotonically-activated $\mathrm{K}-\mathrm{Cl}$ cotransport activity when over-expressed in Xenopus laevis oocytes [50]. However, despite both hKCC3a and hKCC3b exhibiting furosemide-sensitive $\mathrm{K}-\mathrm{Cl}$ cotransport activity when over-expressed in human cell lines, only hKCC3a functionally responds to a hypotonic challenge [18, 20,54]. This is intriguing in the sense that both variants present identical C-terminal regions containing two key threonine residues $\left(\mathrm{Thr}^{991}\right.$ and $\mathrm{Thr}^{1048}$ ) directly involved in swelling-activated cotransport function [55]. Therefore, it is not clear if this functional difference between hKCC3 variants is related to unique amino acid sequences in their N-termini, to differential behavior of the human KCC3s in cells of different species, or even to the presence of cellspecific regulatory constraints. At any rate, the possibilities that some variants of hKCC3 may have redundant transport function or yet undiscovered functions must not be ruled out.

The apparent functional complexity of hKCC3s in vitro is further obscured by the fact that there are no specific pharmacological tools that could be used to individually dissect KCC3s at the functional level. In addition, little is known regarding the expression pattern of the different KCC3 mRNAs in vivo in human tissues and cells [56]. In fact, most of our 


\section{Cellular Physiology Cell Physiol Biochem 2013;32(suppl 1):14-31 \begin{tabular}{l|l|l|l|l}
\hline DOI: 10.1159/000356621 & 2013 S. Karger AG, Basel
\end{tabular} and Biochemistry Publisned onine: December 18, 2013 www.karger.com/cpb}

Gagnon/Di Fulvio: Molecular Analysis of K-Cl Cotransporters

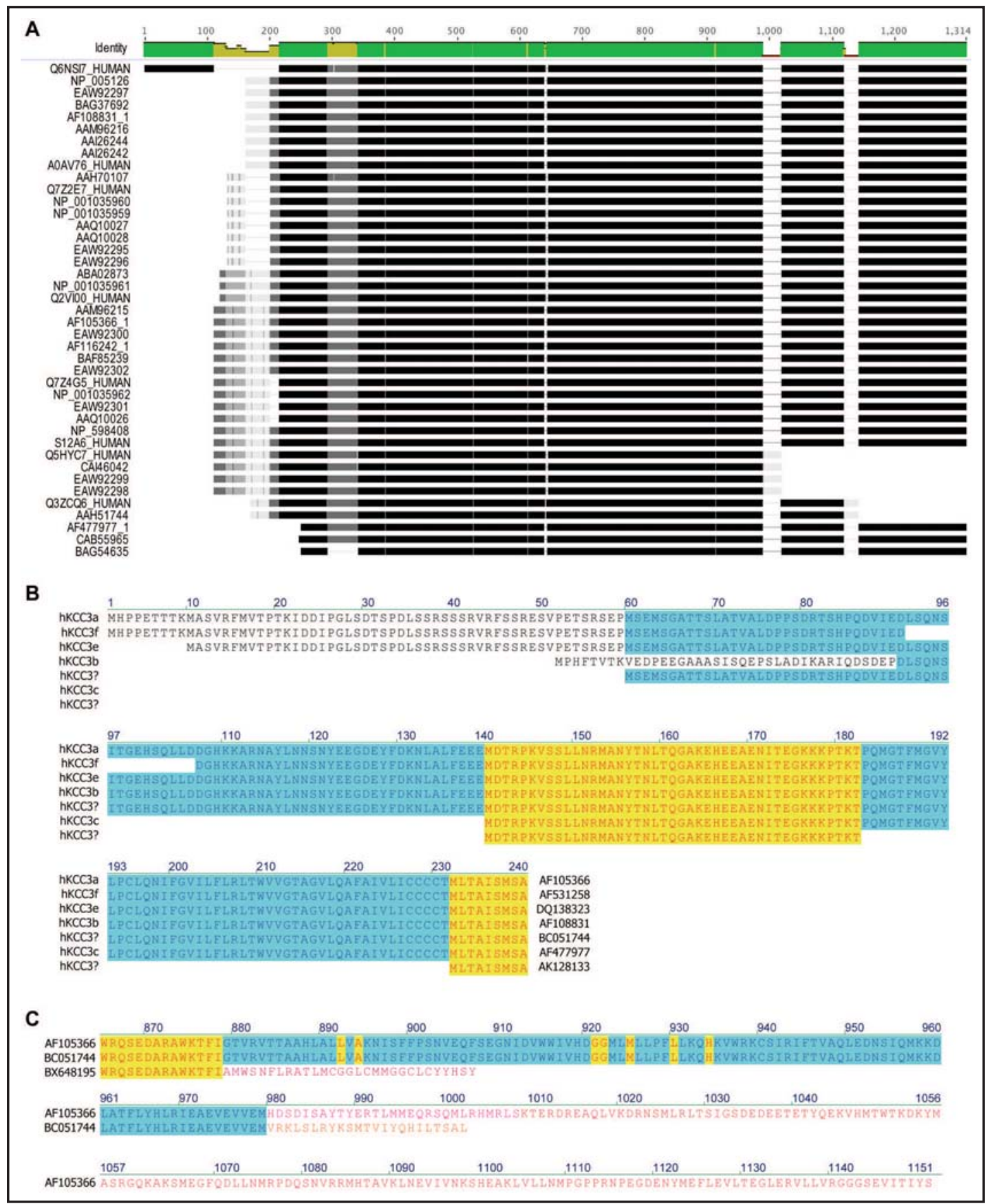

Fig. 6. The potentially exceptional diversity of SLC12A6 proteins. (A) Rough alignment of forty-one protein sequences predicted from human SLC12A6 transcripts and posted in GenBank database under the indicated accession numbers. Alignment was performed using MAFFT v7 [83] and manually organized in clusters to highlight variability in the N- and C-termini of SLC12A6 proteins. The overall degree of identity calculated for all sequences is plotted on top of the alignment. Green and red colors represent $100 \%$ and $0 \%$ identity among sequences, respectively. Variable degrees of identity are represented in the sequences by different shades of grey. (B) Alignment of the most distal region of the N-terminus of hKCC3a (AF105366), hKCC3b (AF108831), hKCC3c (AF477977), hKCC3e (DQ138323), hKCC3f (AF531258) and two SLC12A6 sequences currently awaiting referencing and nomenclature (BC051744 and AK128133). Therefore, they are indicated as KCC3 followed by a question mark and their GenBank accession numbers. (C) Shown is an alignment of the most distal C-terminal region of two unnamed and non-referenced SLC12A6 sequences against the Cterminus of hKCC3a (AF105366). 


\section{Cellular Physiology Cell Physiol Biochem 2013;32(suppl 1):14-31

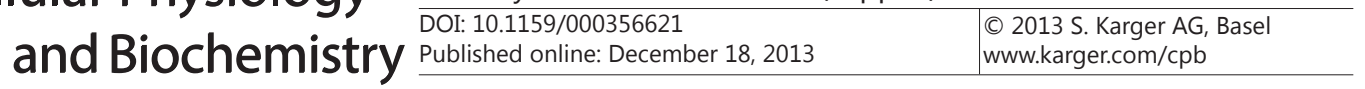 \\ Gagnon/Di Fulvio: Molecular Analysis of K-Cl Cotransporters}

knowledge related to the expression pattern of KCC3 at the protein or transcript levels comes from experiments performed in rodent tissues, notably the central and peripheral nervous systems [38, 50, 51, 57-61]. Nevertheless, the relevance of $S L C 12 A 6$ gene expression in the central and peripheral nervous systems is clear, as mutations in this gene in humans are associated with Andermann's syndrome (Charlevoix disease), a sensorimotor polyneuropathy with or without agenesis of the corpus callosum [62-65]. In mice, mutations in the Slc12a6 gene result in a phenotype that resembles the human condition $[51,66$, 67]. Outside of the nervous system, several lines of evidence suggest that KCC3 may have a physiological impact in vascular homeostasis. At least two variants of KCC3 are expressed in rat or human vascular smooth muscle cells $[18,68,69]$, where their transport function appears to be regulated by nitric oxide and vasodilators [reviewed in [5]]. Furthermore, mice lacking functional KCC3 exhibit increased arterial blood pressure, suggesting that KCC3 activity is associated with vasodilation [51, 70]. However, recent observations suggest that the hypertensive phenotype observed in KCC3 knockout mice is a consequence of elevated sympathetic tone, independent of KCC3 function [52]. Although KCC3 transcripts are relatively abundant in different human or mouse tissues such as heart, skeletal muscle, lung, pancreas or kidney $[19,51]$, the functional impact of this transporter in the physiology of most of these organs still remains unclear.

\section{SLC12A7 (KCC4)}

Molecular aspects

The fourth member of the $\mathrm{Na}^{+}$-independent CCC, KCC4, is produced by the SLC12A7 gene located in the fifth human chromosome (5p15) [19]. The SLC12A7 gene spans $\sim 61 \mathrm{~kb}$ of reverse genomic sequence and contains at least 25 coding exons. Interestingly, exon 23 , which is only $15 \mathrm{bp}$ long, is absent in full-length transcripts derived from this gene as posted in GenBank and annotated in RefSeq database (Fig. 1D). It is important to mention that RefSeq also annotates an SLC12A7 transcript that includes exon 23 (XM_005248231). Although this KCC4 mRNA is supported by RNAseq alignments, its existence as a whole transcript awaits confirmation. As revealed by Northern blot analysis, the transcripts of the SLC12A7 gene appear to be widely distributed in human tissues $[19,71]$. In fact, KCC4 transcripts are highly expressed when compared to average genes in almost all human tissues as judged by the partial or full-length cDNAs/EST sequences reported in GenBank, EST database ( $d b$ EST), and expression profiling of human tissues (Fig. 3).

Among hKCC4 cDNA sequences posted in GenBank, there are four full-length SLC12A7 transcripts annotated with accession numbers AF105365 [tiling clone originally named hKCC3 [19]], BC007760, BC018982 and BC098390 [33]. The first and last hKCC4 cDNAs (AF105365 and BC098390) have been obtained from different sources, but are identical in coding sequences. These characteristics, coupled to the existence of more than 90 ESTs derived from the SLC12A7 gene, are taken as evidence to build a hKCC4 mRNA sequence of reference (RefSeq) defined by the accession number NM_006598 and named here hKCC4a (Table 1).

Two additional full-length hKCC4 clones (BC007760 and BC018982) were obtained from human brain or neuroblastoma cell lines [33]. In silico analysis of these clones, when compared against hKCC4a cDNA sequences, reveals that they are identical in their coding sequence but lack exons 7-24 and the first $119 \mathrm{bp}$ of the last exon 25 (Fig. 1D). Therefore, these transcripts may not encode for $\mathrm{K}-\mathrm{Cl}$ cotransporters, as we know them, but rather very different proteins. An additional, probably incomplete transcript product of the SLC12A7 gene has been obtained from testis and reported in GenBank under accession number AK302856. Similar to BC007760 and BC018982, the AK302856 cDNA joins exonic sequences corresponding to the first $99 \mathrm{bp}$ of exon 6 and the last $73 \mathrm{bp}$ of exon 19 producing a transcript unlikely to encode for a complete $\mathrm{K}-\mathrm{Cl}$ cotransporter. Whether or not these transcripts are widely expressed, or if they even actually produce functional proteins are currently unknown. 


\section{Cellular Physiology Cell Physiol Biochem 2013;32(suppl 1):14-31

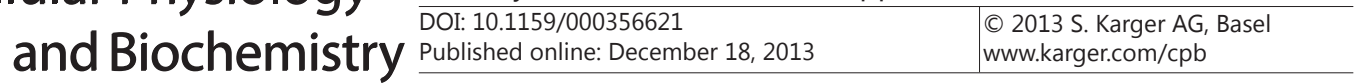 \\ Gagnon/Di Fulvio: Molecular Analysis of K-Cl Cotransporters}

\section{Functional and physiological aspects}

At the protein level, hKCC4a transcripts are predicted to encode a protein of 1083 residues and predicted molecular mass of $\sim 120 \mathrm{kDa}$. However, in cells or tissues of human origin, hKCC4 is detected as bands of higher molecular weight, potentially due to the $\mathrm{N}$-glycosylated nature of the transporter [72], as it was confirmed for the mouse orthologue when over-expressed in human cell lines [73]. Similar to other hKCCs, the amino acid sequence of hKCC4 is predicted to adopt a conformation consisting of 12 transmembrane domains flanked by two large intracellular N- and C-termini. It is in these intracellular domains where specific serine or threonine residues (i.e., $\mathrm{S}^{50}, \mathrm{~S}^{62}, \mathrm{~T}^{926}$ and $\mathrm{T}^{980}$ ) are predicted to modulate co-transport function upon de-phosphorylation [55]. In addition, the predicted extracellular loop interconnecting the fifth and sixth transmembrane domains of hKCC4 contains four putative $\mathrm{N}$-glycosylation sites i.e., $\mathrm{N}^{312}, \mathrm{~N}^{331}, \mathrm{~N}^{344}$ and $\mathrm{N}^{360}$, which are also found in the mouse and rat KCC4, as well as in hKCC1, hKCC2 and hKCC3 (except for $\mathrm{N}^{344}$, which is absent in hKCC1 or hKCC2). As judged by over-expression studies using mouse KCC4 as a model, replacement of $\mathrm{N}^{312}, \mathrm{~N}^{331}, \mathrm{~N}^{344}$ and $\mathrm{N}^{360}$ with $\mathrm{Q}$ renders mKCC4 completely deglycosylated, suggesting that these residues may be subjected to $\mathrm{N}$-glycosylation in vivo [73]. In line, endogenous mKCC 4 is also detected as a protein band of $\sim 145 \mathrm{kDa}$ in certain tissues of the central nervous system of the mouse [74]. However, in other mouse tissues including heart, kidney, liver, and lung where KCC4 transcripts are most prominently expressed [19], endogenous mKCC4 is detected as a protein band of $\sim 120 \mathrm{kDa}$ [75], raising the possibility that N-glycosylation of mKCC4 may be related to expression levels, cell type, or even different antibodies used to detect the transporter in sodium dodecyl sulfate poly-acrylamide gel electrophoresis (SDS-PAGE) immunoblotting experiments.

The functional, pharmacological, regulatory, and kinetic properties of mKCC4 were carefully established by Mount et al. [19] and Mercado et al. [76] using heterologous expression in Xenopus laevis oocytes [reviewed in [4]]. Interestingly, over-expression of mKCC4 resulted in robust $\mathrm{K}-\mathrm{Cl}$ cotransport activity only under hypotonic conditions. Although this characteristic is shared with KCC1 and KCC3, the degree of activation of KCC4 relative to KCC1 was ten times higher [76]. Interestingly, KCC4 was inhibited to different extents, when compared to other KCCs, by different diuretics such as furosemide, bumetanide, trichlormethiazide, butylindazone, or DIDS (4,4-diisothiocyanatostilbene-2,2'disulfonic acid) [19, 76].

Despite the widespread tissue expression of KCC4, targeted global knockout of KCC4 in mice results in two unique non-redundant defects: tubular acidosis (kidney) and deafness (inner ear) [75]. Changes in $\mathrm{pH}$ have been shown to stimulate $\mathrm{K}-\mathrm{Cl}$ cotransport activity in frog oocytes overexpressing KCC4 cRNAs [77]. Together with the basolateral expression of KCC4 in $\alpha$-intercalated cells of the kidney nephron [75], the activity of mKCC4 in conjunction with other transporters may influence the normally high $\mathrm{Cl}^{-} / \mathrm{HCO}_{3}^{-}$exchange capability of $\alpha$-intercalated cells, thus contributing to the observed tubular acidotic phenotype of mice lacking KCC4 [75]. The deafness due to hair cell degeneration is likely a result of targeted knockdown of KCC4 in the supporting cells of outer and inner hair cells, where it is likely to be involved in $\mathrm{K}^{+}$recycling [75].

Interestingly, mKCC4 has also been found abundantly expressed in apical rather than basolateral membranes of several epithelia, notably gastric parietal and choroidal cells, where the cotransporter is proposed to play a role in basal $\mathrm{Cl}^{-}$secretion and $\mathrm{K}^{+}$homeostasis of the cerebrospinal fluid, respectively $[74,78]$. However, no gastric or central phenotypes have been reported in mice lacking KCC4 [75], suggesting that KCC4 activity in these cells may be compensated by the presence of other transporters. In this respect, although human KCC4 has been detected in human and mouse red cells [54], total $\mathrm{K}-\mathrm{Cl}$ cotransport activity is minimal in mouse red cells lacking KCC1 and KCC3 [30]. However, the interpretation of these results warrants caution, as the latter authors did not find evidence of KCC4 protein expression in these cells [30].

The wide distribution of KCC4 in mice and human cells is intriguing, particularly when combined with the fact that KCC4 is stimulated by growth factors such as insulin-like growth 


\section{Cellular Physiology Cell Physiol Biochem 2013;32(suppl 1):14-31 \begin{tabular}{l|l} 
and Biochemistry Por: 10.1159/000356621 & $\begin{array}{l}\text { O 2013 S. Karger AG, Basel } \\
\text { www.karger.com/cpb }\end{array}$ \\
\cline { 2 - 2 }
\end{tabular} \\ Gagnon/Di Fulvio: Molecular Analysis of K-Cl Cotransporters}

factor type I (IGF-I) or epidermal growth factor (EGF) [72, 79], which are usually found over-expressed in several types of cancerous tissues [80, 81]. In fact, recent data suggests that high KCC4 expression in human ovarian and human cervical cancer cells promotes invasiveness and metastatic potential [72], and thus over-overexpression of this transporter in these types of cancers may be related to the worse clinical outcomes observed in patients suffering from those conditions [see review in [22]]. Another interesting finding is that quite often KCC3 is found in tissues expressing KCC4 (see Fig. 3). Given that KCC1, KCC2, KCC3 and KCC4 have all been found to form both homo- or hetero-dimers [28, 29, 48, 49, 53, 82], it is possible that the functional co-expression of these transporters may be subjected to mutual co-regulation.

\section{Conclusion}

Although there are only four genes encoding the $\mathrm{Na}^{+}$-independent $\mathrm{K}-\mathrm{Cl}$ cotransporters in mammals, the number of alternative mRNA variants due to splicing and the potential of some of them to direct protein translation from alternative initiation sites, raises the possibility of multiple protein isoforms and multiple functional outcomes. For instance, human KCC1, which has been thoroughly characterized in almost all tissues, may now actually be considered represented by at least five different proteins. In another example, our analysis indicates the existence of multiple variants of hKCC2 with differential functional properties, expression patterns, and regulation. In fact, this long-time considered neuronalspecific cotransporter has been found in non-neuronal cells with physiological roles independent of the ion transport capabilities of the protein. With more than fifteen cloned mRNAs and at least six potentially different proteins, hKCC3 appears to be represented by the most diverse array of transcript variants. Our in silico analysis has identified multiple variants of hKCC1, hKCC2 and hKCC3 which differ at their $\mathrm{N}$ - or C-termini. These regions are proposed to have important direct or indirect regulatory roles in the function of not only their respective transporter, but also in their ability to regulate the fate of one another through hetero-dimerization. Contrary to hKCC1, hKCC2, and hKCC3, a single variant of hKCC4 has been cloned and characterized. Although this fact does not preclude discovery of new KCC4 variants in the future, it would be interesting to genetically re-examine the functional studies done over the last 30 years in various tissues to determine if what was once considered $\mathrm{K}-\mathrm{Cl}$ cotransport through one isoform (e.g., KCC1 activity) may actually represent a functional combination of multiple variants and/or alternatively-spliced isoforms.

\section{Conflict of Interests}

No conflicts of interest, financial or otherwise, are declared by the authors.

\section{Acknowledgments}

We are grateful to Wright State University Boonshoft School of Medicine for supporting MDiF through the Seed Grant Program and the Saskatchewan Health Research Foundation Research Group Grant for supporting KBG.

\section{References}

1 Di Fulvio M, Alvarez-Leefmans FJ: The NKCC and NCC Genes: An in silico view.; in Alvarez-Leefmans FJ, Delpire E (eds): Physiology and Pathology of Chloride Transporters and Channels in the Nervous System: From Molecules to Diseases. London, Academic Press, Incorporated, 2009, pp 169-208. 


\section{Cellular Physiology Cell Physiol Biochem 2013;32(suppl 1):14-31 \begin{tabular}{c|c}
\hline DOI: 10.1159/000356621 & C) 2013 S. Karger AG, Basel
\end{tabular} and Biochemistry Published online: December 18, $2013 \quad$ www.karger.com/cpb}

Gagnon/Di Fulvio: Molecular Analysis of K-Cl Cotransporters

-2 Daigle ND, Carpentier GA, Frenette-Cotton R, Simard MG, Lefoll MH, Noel M, Caron L, Noel J, Isenring P: Molecular characterization of a human cation-Cl- cotransporter (SLC12A8A, CCC9A) that promotes polyamine and amino acid transport. J Cell Physiol 2009;220:680-689.

3 Caron L, Rousseau F, Gagnon E, Isenring P: Cloning and functional characterization of a cation-Clcotransporter-interacting protein. J Biol Chem 2000;275:32027-32036.

-4 Alvarez-Leefmans F: Intracellular Chloride Regulation; in Cell Physiology Sourcebook: Essentials of Membrance Biophysics; in Amsterdam; Boston, Elsevier/AP, 2012, pp 221-259.

5 Adragna NC, Di Fulvio M, Lauf PK: Regulation of K-Cl cotransport: from function to genes. J Membr Biol 2004;201:109-137.

6 Payne JA: Functional characterization of the neuronal-specific $\mathrm{K}-\mathrm{Cl}$ cotransporter: implications for [K+]o regulation. Am J Physiol 1997;273:C1516-1525.

-7 Jean-Xavier C, Pflieger JF, Liabeuf S, Vinay L: Inhibitory postsynaptic potentials in lumbar motoneurons remain depolarizing after neonatal spinal cord transection in the rat. J Neurophysiol 2006;96:2274-2281.

-8 Reid KH, Guo SZ, Iyer VG: Agents which block potassium-chloride cotransport prevent sound-triggered seizures in post-ischemic audiogenic seizure-prone rats. Brain Res 2000;864:134-137.

-9 Jessen F, Sjoholm C, Hoffmann EK: Identification of the anion exchange protein of Ehrlich cells: a kinetic analysis of the inhibitory effects of 4,4'-diisothiocyano-2,2'-stilbene-disulfonic acid (DIDS) and labeling of membrane proteins with 3H-DIDS. J Membr Biol 1986;92:195-205.

10 Lane M, Baltz JM, Bavister BD: Bicarbonate/chloride exchange regulates intracellular pH of embryos but not oocytes of the hamster. Biol Reprod 1999;61:452-457.

$\checkmark 11$ Matulef K, Howery AE, Tan L, Kobertz WR, Du Bois J, Maduke M: Discovery of potent CLC chloride channel inhibitors. ACS Chem Biol 2008;3:419-428.

12 Delpire E, Lauf PK: Kinetics of DIDS inhibition of swelling-activated K-Cl cotransport in low K sheep erythrocytes. J Membr Biol 1992;126:89-96.

13 Fujii T, Ohira Y, Itomi Y, Takahashi Y, Asano S, Morii M, Takeguchi N, Sakai H: Inhibition of P-type ATPases by [(dihydroindenyl)oxy] acetic acid (DIOA), a K+ -Cl- cotransporter inhibitor. Eur J Pharmacol 2007;560:123126.

14 Delpire E, Days E, Lewis LM, Mi D, Kim K, Lindsley CW, Weaver CD: Small-molecule screen identifies inhibitors of the neuronal K-Cl cotransporter KCC2. Proc Natl Acad Sci U S A 2009;106:5383-5388.

15 Delpire E, Baranczak A, Waterson AG, Kim K, Kett N, Morrison RD, Daniels JS, Weaver CD, Lindsley CW: Further optimization of the K-Cl cotransporter KCC2 antagonist ML077: development of a highly selective and more potent in vitro probe. Bioorg Med Chem Lett 2012;22:4532-4535.

16 Gillen CM, Brill S, Payne JA, Forbush B, 3rd: Molecular cloning and functional expression of the K-Cl cotransporter from rabbit, rat, and human. A new member of the cation-chloride cotransporter family. J Biol Chem 1996;271:16237-16244.

-17 Payne JA, Stevenson TJ, Donaldson LF: Molecular characterization of a putative K-Cl cotransporter in rat brain. A neuronal-specific isoform. J Biol Chem 1996;271:16245-16252.

18 Hiki K, D'Andrea RJ, Furze J, Crawford J, Woollatt E, Sutherland GR, Vadas MA, Gamble JR: Cloning, characterization, and chromosomal location of a novel human $\mathrm{K}+-\mathrm{Cl}$ - cotransporter. J Biol Chem 1999;274:10661-10667.

19 Mount DB, Mercado A, Song L, Xu J, George AL Jr, Delpire E, Gamba G: Cloning and characterization of KCC3 and KCC4, new members of the cation-chloride cotransporter gene family. J Biol Chem 1999;274:1635516362.

20 Race JE, Makhlouf FN, Logue PJ, Wilson FH, Dunham PB, Holtzman EJ: Molecular cloning and functional characterization of KCC3, a new K-Cl cotransporter. Am J Physiol 1999;277:C1210-1219.

-21 Payne JA: The Potassium-Chloride Cotransporters: from Cloning to Structure and Function.; in AlvarezLeefmans FJ, Delpire E (eds): Physiology and Pathology of Chloride Transporters and Channels in the Nervous System: From Molecules to Diseases. London, Academic Press, Incorporated, 2009, pp 333-356.

-22 Gagnon KB, Delpire E: Physiology of SLC12 transporters: lessons from inherited human genetic mutations and genetically engineered mouse knockouts. Am J Physiol Cell Physiol 2013;304:C693-714.

-23 Li H, Khirug S, Cai C, Ludwig A, Blaesse P, Kolikova J, Afzalov R, Coleman SK, Lauri S, Airaksinen MS, Keinanen K, Khiroug L, Saarma M, Kaila K, Rivera C: KCC2 interacts with the dendritic cytoskeleton to promote spine development. Neuron 2007;56:1019-1033. 


\section{Cellular Physiology Cell Physiol Biochem 2013;32(suppl 1):14-31 \begin{tabular}{l|l|l} 
DOI: 10.1159/000356621 & O 2013 S. Karger AG, Basel
\end{tabular} and Biochemistry Publisned online: December 18, 2013 www.karger.com/cpb}

Gagnon/Di Fulvio: Molecular Analysis of K-Cl Cotransporters

24 Horn Z, Ringstedt T, Blaesse P, Kaila K, Herlenius E: Premature expression of KCC2 in embryonic mice perturbs neural development by an ion transport-independent mechanism. Eur J Neurosci 2010;31:21422155.

-25 Wei WC, Akerman CJ, Newey SE, Pan J, Clinch NW, Jacob Y, Shen MR, Wilkins RJ, Ellory JC: The potassiumchloride cotransporter 2 promotes cervical cancer cell migration and invasion by an ion transportindependent mechanism. J Physiol 2011;589:5349-5359.

-26 Fiumelli H, Briner A, Puskarjov M, Blaesse P, Belem BJ, Dayer AG, Kaila K, Martin JL, Vutskits L: An Ion Transport-Independent Role for the Cation-Chloride Cotransporter KCC2 in Dendritic Spinogenesis In Vivo. Cereb Cortex 2013;23:378-388.

27 Pellegrino CM, Rybicki AC, Musto S, Nagel RL, Schwartz RS: Molecular identification and expression of erythroid K:Cl cotransporter in human and mouse erythroleukemic cells. Blood Cells Mol Dis 1998;24:3140.

28 Casula S, Shmukler BE, Wilhelm S, Stuart-Tilley AK, Su W, Chernova MN, Brugnara C, Alper SL: A dominant negative mutant of the $\mathrm{KCC} 1 \mathrm{~K}-\mathrm{Cl}$ cotransporter: both $\mathrm{N}$ - and C-terminal cytoplasmic domains are required for K-Cl cotransport activity. J Biol Chem 2001;276:41870-41878.

-29 Casula S, Zolotarev AS, Stuart-Tilley AK, Wilhelm S, Shmukler BE, Brugnara C, Alper SL: Chemical crosslinking studies with the mouse Kcc1 K-Cl cotransporter. Blood Cells Mol Dis 2009;42:233-240.

30 Rust MB, Alper SL, Rudhard Y, Shmukler BE, Vicente R, Brugnara C, Trudel M, Jentsch TJ, Hubner CA: Disruption of erythroid $\mathrm{K}-\mathrm{Cl}$ cotransporters alters erythrocyte volume and partially rescues erythrocyte dehydration in SAD mice. J Clin Invest 2007;117:1708-1717.

-31 Uvarov P, Ludwig A, Markkanen M, Pruunsild P, Kaila K, Delpire E, Timmusk T, Rivera C, Airaksinen MS: A novel N-terminal isoform of the neuron-specific K-Cl cotransporter KCC2. J Biol Chem 2007;282:3057030576.

-32 Song L, Mercado A, Vazquez N, Xie Q, Desai R, George AL Jr, Gamba G, Mount DB: Molecular, functional, and genomic characterization of human KCC2, the neuronal K-Cl cotransporter. Brain Res Mol Brain Res 2002;103:91-105.

33 Strausberg RL, Feingold EA, Grouse LH, Derge JG, Klausner RD, Collins FS, Wagner L, Shenmen CM, Schuler GD, Altschul SF, Zeeberg B, Buetow KH, Schaefer CF, Bhat NK, Hopkins RF, Jordan H, Moore T, Max SI, Wang J, Hsieh F, Diatchenko L, Marusina K, Farmer AA, Rubin GM, Hong L, Stapleton M, Soares MB, Bonaldo MF, Casavant TL, Scheetz TE, Brownstein MJ, Usdin TB, Toshiyuki S, Carninci P, Prange C, Raha SS, Loquellano NA, Peters GJ, Abramson RD, Mullahy SJ, Bosak SA, McEwan PJ, McKernan KJ, Malek JA, Gunaratne PH, Richards S, Worley KC, Hale S, Garcia AM, Gay LJ, Hulyk SW, Villalon DK, Muzny DM, Sodergren EJ, Lu X, Gibbs RA, Fahey J, Helton E, Ketteman M, Madan A, Rodrigues S, Sanchez A, Whiting M, Madan A, Young AC, Shevchenko Y, Bouffard GG, Blakesley RW, Touchman JW, Green ED, Dickson MC, Rodriguez AC, Grimwood J, Schmutz J, Myers RM, Butterfield YS, Krzywinski MI, Skalska U, Smailus DE, Schnerch A, Schein JE, Jones SJ, Marra MA: Generation and initial analysis of more than 15,000 full-length human and mouse cDNA sequences. Proc Natl Acad Sci U S A 2002;99:16899-16903.

-34 Lauf PK, Di Fulvio M, Srivastava V, Sharma N, Adragna NC: KCC2a Expression in a Human Fetal Lens Epithelial Cell Line. Cell Physiol Biochem 2012;29:303-312.

-35 Antrobus SP, Lytle C, Payne JA: K+-Cl- cotransporter-2 KCC2 in chicken cardiomyocytes. Am J Physiol Cell Physiol 2012;303:C1180-1191.

36 Taneera J, Jin Z, Jin Y, Muhammed SJ, Zhang E, Lang S, Salehi A, Korsgren O, Renstrom E, Groop L, Birnir B: gamma-Aminobutyric acid (GABA) signalling in human pancreatic islets is altered in type 2 diabetes. Diabetologia 2012;55:1985-1994.

-37 Di Fulvio M, Lincoln TM, Lauf PK, Adragna NC: Protein kinase G regulates potassium chloride cotransporter-3 expression in primary cultures of rat vascular smooth muscle cells. J Biol Chem 2001;276:21046-21052.

-38 Mao S, Garzon-Muvdi T, Di Fulvio M, Chen Y, Delpire E, Alvarez FJ, Alvarez-Leefmans FJ: Molecular and functional expression of cation-chloride cotransporters in dorsal root ganglion neurons during postnatal maturation. J Neurophysiol 2012;108:834-852.

39 Kahle KT, Staley KJ, Nahed BV, Gamba G, Hebert SC, Lifton RP, Mount DB: Roles of the cation-chloride cotransporters in neurological disease. Nat Clin Pract Neurol 2008;4:490-503.

40 Blaesse P, Airaksinen MS, Rivera C, Kaila K: Cation-chloride cotransporters and neuronal function. Neuron 2009;61:820-838. 


\section{Cellular Physiology Cell Physiol Biochem 2013;32(suppl 1):14-31 \begin{tabular}{ll|l} 
and Biochemistry & $\begin{array}{l}\text { DOI: 10.1159/000356621 } \\
\text { Publisned online: December 18, } 2013\end{array}$ & $\begin{array}{l}\text { c 2013 S. Karger AG, Basel } \\
\text { www.karger.com/cpb }\end{array}$ \\
\hline
\end{tabular}}

41 Chamma I, Chevy Q Poncer JC, Levi S: Role of the neuronal K-Cl co-transporter KCC2 in inhibitory and excitatory neurotransmission. Front Cell Neurosci 2012;6:5.

42 Brauer M, Frei E, Claes L, Grissmer S, Jager H: Influence of K-Cl cotransporter activity on activation of volume-sensitive Cl- channels in human osteoblasts. Am J Physiol Cell Physiol 2003;285:C22-30.

43 Kanaka C, Ohno K, Okabe A, Kuriyama K, Itoh T, Fukuda A, Sato K: The differential expression patterns of messenger RNAs encoding $\mathrm{K}-\mathrm{Cl}$ cotransporters (KCC1,2) and Na-K-2Cl cotransporter (NKCC1) in the rat nervous system. Neuroscience 2001;104:933-946.

44 Mercado A, Broumand V, Zandi-Nejad K, Enck AH, Mount DB: A C-terminal domain in KCC2 confers constitutive K+-Cl- cotransport. J Biol Chem 2006;281:1016-1026.

45 Hubner CA, Stein V, Hermans-Borgmeyer I, Meyer T, Ballanyi K, Jentsch TJ: Disruption of KCC2 reveals an essential role of K-Cl cotransport already in early synaptic inhibition. Neuron 2001;30:515-524.

-46 Tornberg J, Voikar V, Savilahti H, Rauvala H, Airaksinen MS: Behavioural phenotypes of hypomorphic KCC2deficient mice. Eur J Neurosci 2005;21:1327-1337.

47 Woo NS, Lu J, England R, McClellan R, Dufour S, Mount DB, Deutch AY, Lovinger DM, Delpire E: Hyperexcitability and epilepsy associated with disruption of the mouse neuronal-specific K-Cl cotransporter gene. Hippocampus 2002;12:258-268.

-48 Blaesse P, Guillemin I, Schindler J, Schweizer M, Delpire E, Khiroug L, Friauf E, Nothwang HG: Oligomerization of KCC2 correlates with development of inhibitory neurotransmission. J Neurosci 2006;26:10407-10419.

49 Uvarov P, Ludwig A, Markkanen M, Soni S, Hubner CA, Rivera C, Airaksinen MS: Coexpression and heteromerization of two neuronal $\mathrm{K}-\mathrm{Cl}$ cotransporter isoforms in neonatal brain. J Biol Chem 2009;284:13696-13704.

50 Mercado A, Vazquez N, Song L, Cortes R, Enck AH, Welch R, Delpire E, Gamba G, Mount DB: NH2-terminal heterogeneity in the KCC3 K+-Cl- cotransporter. Am J Physiol Renal Physiol 2005;289:F1246-1261.

51 Boettger T, Rust MB, Maier H, Seidenbecher T, Schweizer M, Keating DJ, Faulhaber J, Ehmke H, Pfeffer C, Scheel O, Lemcke B, Horst J, Leuwer R, Pape HC, Volkl H, Hubner CA, Jentsch TJ: Loss of K-Cl co-transporter KCC3 causes deafness, neurodegeneration and reduced seizure threshold. EMBO J 2003;22:5422-5434.

52 Rust MB, Faulhaber J, Budack MK, Pfeffer C, Maritzen T, Didie M, Beck FX, Boettger T, Schubert R, Ehmke H, Jentsch TJ, Hubner CA: Neurogenic mechanisms contribute to hypertension in mice with disruption of the K-Cl cotransporter KCC3. Circ Res 2006;98:549-556.

53 Ding J, Ponce-Coria J, Delpire E: A trafficking-deficient mutant of KCC3 reveals dominant-negative effects on K-Cl cotransport function. PLoS One 2013;8:e61112.

54 Pan D, Kalfa TA, Wang D, Risinger M, Crable S, Ottlinger A, Chandra S, Mount DB, Hubner CA, Franco RS, Joiner $\mathrm{CH}$ : $\mathrm{K}-\mathrm{Cl}$ cotransporter gene expression during human and murine erythroid differentiation. J Biol Chem 2011;286:30492-30503.

55 Rinehart J, Maksimova YD, Tanis JE, Stone KL, Hodson CA, Zhang J, Risinger M, Pan W, Wu D, Colangelo CM, Forbush B, Joiner CH, Gulcicek EE, Gallagher PG, Lifton RP: Sites of regulated phosphorylation that control K-Cl cotransporter activity. Cell 2009;138:525-536.

56 Fujii T, Takahashi Y, Itomi Y, Fujita K, Morii M, Tabuchi Y, Asano S, Tsukada K, Takeguchi N, Sakai H: K+-ClCotransporter-3a Up-regulates Na+,K+-ATPase in Lipid Rafts of Gastric Luminal Parietal Cells. J Biol Chem 2008;283:6869-6877.

57 Pearson MM, Lu J, Mount DB, Delpire E: Localization of the K(+)-Cl(-) cotransporter, KCC3, in the central and peripheral nervous systems: expression in the choroid plexus, large neurons and white matter tracts. Neuroscience 2001;103:481-491.

58 Becker M, Nothwang HG, Friauf E: Differential expression pattern of chloride transporters NCC, NKCC2, KCC1, KCC3, KCC4, and AE3 in the developing rat auditory brainstem. Cell Tissue Res 2003;312:155-165.

59 Le Rouzic P, Ivanov TR, Stanley PJ, Baudoin FM, Chan F, Pinteaux E, Brown PD, Luckman SM: KCC3 and KCC4 expression in rat adult forebrain. Brain Res 2006;1110:39-45.

60 Shekarabi M, Salin-Cantegrel A, Laganiere J, Gaudet R, Dion P, Rouleau GA: Cellular expression of the K+-Clcotransporter KCC3 in the central nervous system of mouse. Brain Res 2011;1374:15-26.

61 Lucas O, Hilaire C, Delpire E, Scamps F: KCC3-dependent chloride extrusion in adult sensory neurons. Mol Cell Neurosci 2012;50:211-220.

62 Howard HC, Mount DB, Rochefort D, Byun N, Dupre N, Lu J, Fan X, Song L, Riviere JB, Prevost C, Horst J, Simonati A, Lemcke B, Welch R, England R, Zhan FQ, Mercado A, Siesser WB, George AL Jr, McDonald MP, Bouchard JP, Mathieu J, Delpire E, Rouleau GA: The K-Cl cotransporter KCC3 is mutant in a severe peripheral neuropathy associated with agenesis of the corpus callosum. Nat Genet 2002;32:384-392. 


\section{Cellular Physiology Cell Physiol Biochem 2013;32(suppl 1):14-31 \begin{tabular}{l|l}
\hline DOI: 10.1159/000356621 & (c) 2013 S. Karger AG, Basel
\end{tabular} and Biochemistry Published online: December 18, $2013 \quad$ www.karger.com/cpb}

Gagnon/Di Fulvio: Molecular Analysis of K-Cl Cotransporters

63 Dupre N, Howard HC, Rouleau GA: Hereditary Motor and Sensory Neuropathy with Agenesis of the Corpus Callosum; in Pagon RA, Adam MP, Bird TD, Dolan CR, Fong CT, Stephens K (eds): GeneReviews. University of Washington, Seattle (WA), 1993.

64 Salin-Cantegrel A, Riviere JB, Shekarabi M, Rasheed S, Dacal S, Laganiere J, Gaudet R, Rochefort D, Lesca G, Gaspar C, Dion PA, Lapointe JY, Rouleau GA: Transit defect of potassium-chloride Co-transporter 3 is a major pathogenic mechanism in hereditary motor and sensory neuropathy with agenesis of the corpus callosum. J Biol Chem 2011;286:28456-28465.

65 Shekarabi M, Moldrich RX, Rasheed S, Salin-Cantegrel A, Laganiere J, Rochefort D, Hince P, Huot K, Gaudet R, Kurniawan N, Sotocinal SG, Ritchie J, Dion PA, Mogil JS, Richards LJ, Rouleau GA: Loss of neuronal potassium/chloride cotransporter 3 (KCC3) is responsible for the degenerative phenotype in a conditional mouse model of hereditary motor and sensory neuropathy associated with agenesis of the corpus callosum. J Neurosci 2012;32:3865-3876.

66 Jiao Y, Jin X, Yan J, Zhang C, Jiao F, Li X, Roe BA, Mount DB, Gu W: A deletion mutation in Slc12a6 is associated with neuromuscular disease in gaxp mice. Genomics 2008;91:407-414.

67 Sun YT, Lin TS, Tzeng SF, Delpire E, Shen MR: Deficiency of electroneutral K+-Cl- cotransporter 3 causes a disruption in impulse propagation along peripheral nerves. Glia 2010;58:1544-1552.

68 Di Fulvio M, Lauf PK, Adragna NC: The NO signaling pathway differentially regulates KCC3a and KCC3b mRNA expression. Nitric Oxide 2003;9:165-171.

69 Di Fulvio M, Lauf PK, Shah S, Adragna NC: NONOates regulate KCl cotransporter-1 and -3 mRNA expression in vascular smooth muscle cells. Am J Physiol Heart Circ Physiol 2003;284:H1686-1692.

-70 Adragna NC, Chen Y, Delpire E, Lauf PK, Morris M: Hypertension in K-Cl cotransporter-3 knockout mice. Adv Exp Med Biol 2004;559:379-385.

-71 Hattori A, Okumura K, Nagase T, Kikuno R, Hirosawa M, Ohara O: Characterization of long cDNA clones from human adult spleen. DNA Res 2000;7:357-366.

72 Chen YF, Chou CY, Wilkins RJ, Ellory JC, Mount DB, Shen MR: Motor protein-dependent membrane trafficking of $\mathrm{KCl}$ cotransporter-4 is important for cancer cell invasion. Cancer Res 2009;69:8585-8593.

73 Weng TY, Chiu WT, Liu HS, Cheng HC, Shen MR, Mount DB, Chou CY: Glycosylation regulates the function and membrane localization of KCC4. Biochim Biophys Acta 2013;1833:1133-1146.

74 Karadsheh MF, Byun N, Mount DB, Delpire E: Localization of the KCC4 potassium-chloride cotransporter in the nervous system. Neuroscience 2004;123:381-391.

75 Boettger T, Hubner CA, Maier H, Rust MB, Beck FX, Jentsch TJ: Deafness and renal tubular acidosis in mice lacking the K-Cl co-transporter Kcc4. Nature 2002;416:874-878.

76 Mercado A, Song L, Vazquez N, Mount DB, Gamba G: Functional comparison of the K+-Cl- cotransporters KCC1 and KCC4. J Biol Chem 2000;275:30326-30334.

-77 Bergeron MJ, Gagnon E, Wallendorff B, Lapointe JY, Isenring P: Ammonium transport and pH regulation by K(+)-Cl(-) cotransporters. Am J Physiol Renal Physiol 2003;285:F68-78.

78 Fujii T, Takahashi Y, Ikari A, Morii M, Tabuchi Y, Tsukada K, Takeguchi N, Sakai H: Functional association between $\mathrm{K}+-\mathrm{Cl}$ - cotransporter-4 and $\mathrm{H}+, \mathrm{K}+$-ATPase in the apical canalicular membrane of gastric parietal cells. J Biol Chem 2009;284:619-629.

79 Hsu YM, Chou CY, Chen HH, Lee WY, Chen YF, Lin PW, Alper SL, Ellory JC, Shen MR: IGF-1 upregulates electroneutral $\mathrm{K}-\mathrm{Cl}$ cotransporter $\mathrm{KCC} 3$ and $\mathrm{KCC} 4$ which are differentially required for breast cancer cell proliferation and invasiveness. J Cell Physiol 2007;210:626-636.

80 Arcaro A: Targeting the insulin-like growth factor-1 receptor in human cancer. Front Pharmacol 2013;4:30.

81 Goffin JR, Zbuk K: Epidermal growth factor receptor: pathway, therapies, and pipeline. Clin Ther 2013;35:1282-1303.

-82 Simard CF, Bergeron MJ, Frenette-Cotton R, Carpentier GA, Pelchat ME, Caron L, Isenring P: Homooligomeric and heterooligomeric associations between $\mathrm{K}+-\mathrm{Cl}$ - cotransporter isoforms and between K+-Cl- and Na+-K+-Cl- cotransporters. J Biol Chem 2007;282:18083-18093.

83 Katoh K, Misawa K, Kuma K, Miyata T: MAFFT: a novel method for rapid multiple sequence alignment based on fast Fourier transform. Nucleic Acids Res 2002;30:3059-3066.

84 Su AI, Wiltshire T, Batalov S, Lapp H, Ching KA, Block D, Zhang J, Soden R, Hayakawa M, Kreiman G, Cooke MP, Walker JR, Hogenesch JB: A gene atlas of the mouse and human protein-encoding transcriptomes. Proc Natl Acad Sci USA 2004;101:6062-6067. 